\title{
Effect of glucocorticoids on lysosomes in synovial lining cells in human rheumatoid arthritis
}

\author{
LUCILLE BITENSKY, R. G. BUTCHER, J. J. JOHNSTONE, AND J. CHAYEN \\ Division of Cellular Biology, The Kennedy Institute of Rheumatology, Hammersmith, London W6 7DW
}

It is now generally conceded that lysosomal instability in tissues of the rheumatoid joint play some part in the rheumatoid process either directly (e.g. Weissmann, 1966, 1967; Page Thomas, 1967, 1969; Chayen and Bitensky, 1971) or by means of an immunological response (Hollander, McCarty, Astorga, and Castro-Murillo, 1965; Weissmann, 1966, 1967; Page Thomas, 1969). Although the critical site of the altered lysosomes was originally sought in the free cells of the synovial fluid, the work of Ball (1968) indicated that the primary site was in the synovial reflexions of the joint. This view gained support from the study by Muirden and Mills (1971), who found that there was no correlation between the degree of joint damage and the amount of lymphocytic infiltration in $\mathbf{4 2}$ joints examined. On the other hand there was a significant correlation between the amount of lining cell proliferation and joint damage. Moreover, Muirden (1972) found that high levels of lysosomal enzymes were found in joints in which the histology was dominated by the proliferation of synovial lining cells.

Glucocorticoids such as hydrocortisone or related synthetic analogues have been much used in the treatment of rheumatoid arthritis. Their mode of action, in this context, is not entirely clear. There is good evidence that such corticosteroids can stabilize the membranes of isolated lysosomes (Weissmann, 1968, 1969; Allison, 1968) and some evidence that they may act similarly when applied to living cells (Weissmann, 1969). Lewis and Day (1972) adduced evidence that corticosteroids may stabilize the lysosomes of the free cells in synovial fluid; they presented indirect evidence that a similar effect pertained in rheumatoid synovial tissue but they were not able to show in which cells this response occurred.

In view of these considerations it seemed reasonable to examine the effect of natural and synthetic glucocorticoids on the lysosomes of human synovial lining cells specifically, separate from their effect on lysosomes of the mass of synovial tissue with its very heterogeneous population of diverse cell types. This can be achieved by microdensitometry of the quantitative cytochemical reactions of the lysosomes, the synovial lining cells being measured separately from the other cell types by optical means (Chayen, Bitensky, Butcher, and Cashman, 1971; Bitensky, Butcher, and Chayen, 1973). The effect of the steroids could be investigated in synovial biopsies from patients treated with glucocorticoids. To confirm that any observed effects were due to the directo action of these steroids, it was also possible to studye their effects in vitro, because it has now been demonstrated that human synovial tissue can be maintained in non-proliferative culture in such a way that, in all respects studied, it is structurally and chemically identical with the tissue at the time of the biopsy (Poulter, Bitensky, Cashman, and Chayen, 1970; Chayen, Bitensky, Butcher, and Cashman, 1973).

\section{Material}

Thirteen specimens were examined from twelve patients who had been treated with at least $5 \mathrm{mg}$./day prednisolone, one specimen from a patient treated with Acthar gel, and fifteen specimens from thirteen patients who had been treated with $4 \mathrm{mg}$./day or less, or who had not been treated with glucocorticoids at all (Table I, overleaf). All had 'definite' or 'classical' rheumatoid arthritis, according to the diagnostic criteria of the American Rheumatism Association (Ropes, Bennett, Cobb, Jacox, and Jessar, 1959). These specimens were obtained at synovectomy.

In addition, some specimens of non-rheumatoid synovial tissue were obtained during routine arthrotomy for internal derangements.

Selected pieces (not larger than $5 \times 3 \times 3 \mathrm{~mm}$.) of the specimens were chilled by precipitate immersion at $-70^{\circ} \mathrm{C}$. in $n$-hexane (B.D.H. 'free from aromatic hydrocarbon' grade) for up to $1 \mathrm{~min}$. before being stored in a dry tube at $-70^{\circ} \mathrm{C}$. Other specimens were cut into small pieces and maintained in vitro, in Trowell maintenance culture (Trowell, 1959; Poulter and others, 1970) for 20 to $24 \mathrm{hrs}$. Various concentrations of glucocorticoids were added to the Trowell T8 medium used for maintaining some of these specimens. Where water-insoluble steroids were used, these were added dissolved in alcohol to 
Table I Specimens and patients studied

(a) Those treated with less than $5 \mathrm{mg} . /$ day prednisolone or only with non-steroidal drugs

\begin{tabular}{|c|c|c|}
\hline Specimen no. & Sex & Age (yrs) \\
\hline $\begin{array}{l}1029 \\
1052 \\
1057 \\
1080 \\
1084 \\
1128 \\
1176 \\
1182 \\
1211 \\
1233 \\
1260 \\
1345 \\
1429 \\
1503 \\
1510 \\
1212^{*} \\
1430^{*}\end{array}$ & $\begin{array}{l}F \\
F \\
F \\
F \\
F \\
F \\
F \\
F \\
F \\
F \\
F \\
F \\
F\end{array}$ & $\begin{array}{l}58 \dagger \\
58 \\
63 \\
52 \dagger \\
43 \\
54 \dagger \\
55 \\
48 \dagger \\
46 \\
35 \\
50 \\
43 \\
46\end{array}$ \\
\hline
\end{tabular}

(b) Those treated with at least $5 \mathrm{mg}$./day prednisolone or with ACTH

\begin{tabular}{|c|c|c|c|}
\hline Specimen no. & Sex & Age (yrs) & $\begin{array}{l}\text { Duration of } \\
\text { therapy (yrs) }\end{array}$ \\
\hline \multirow{3}{*}{$\begin{array}{l}1022 \\
1078 \\
1085 \\
1089 \\
1205 \\
1267 \\
1298 \\
1329 \\
1339 \\
1349 \\
1373 \\
1445 \\
1462\end{array}$} & $\begin{array}{l}F \\
F\end{array}$ & $\begin{array}{l}50 \\
59\end{array}$ & $\begin{array}{l}9 \\
4\end{array}$ \\
\hline & $\mathrm{F}$ & 62 & 5 \\
\hline & $\begin{array}{l}\mathbf{F} \\
\mathbf{M} \\
\mathbf{F} \\
\mathbf{M} \\
\mathbf{F} \\
\mathbf{M} \\
\mathbf{M} \\
\mathbf{F} \\
\mathbf{F}\end{array}$ & $\begin{array}{l}65 \\
78 \\
60 \\
50 \\
29 \\
42 \\
55 \\
45 \\
69\end{array}$ & $\begin{array}{c}5 \\
3 \\
3 \\
7 \\
2 \\
4 \cdot 5 \\
12 \\
4 \\
3\end{array}($ ACTH $)$ \\
\hline
\end{tabular}

* Used for in vitro studies only.

+ Treated with less than $5 \mathrm{mg}$./day prednisolone.

All patients treated with prednisolone were given $100 \mathrm{mg}$. hydrocortisone with the premedication immediately before operation. This was too short a time for the hydrocortisone to achieve an effect on the synovial cell lysosomes.

achieve a final concentration of 1 per cent. alcohol in the T8 medium. In such studies 1 per cent. of alcohol was added to the medium used for the 'control' tissue. After maintenance culture these specimens were chilled and stored as were the biopsies.

\section{Methods}

The chilled tissues were sectioned at $10 \mu \mathrm{m}$. in a Bright's cryostat with the cabinet temperature at $-25^{\circ} \mathrm{C}$. and with the knife cooled by having its haft packed around with cardice. The unfixed sections were subjected to the quantitative cytochemical test for lysosomal naphthylamidase activity with and without acid pretreatment for testing the stability of the lysosomal membranes, as discussed fully by Chayen and others (1971) and by Bitensky and others (1973). Other sections were tested by the acid phosphatase test for lysosomes and lysosomal fragility (Bitensky, 1963; Bitensky and others, 1973). All the cytochemical methods have been described in detail by Chayen, Bitensky, Butcher, and Poulter (1969) and Chayen, Bitensky, and Butcher (1973). The naphthylamidase reaction was measured in the synovial lining cells selectively by means of a Barr and Stroud GN2 scanning and integrating microdensitometer, with a $\times 100$ oil immersion objective; this gave a scanning spot equivalent to a spot $0.25 \mu \mathrm{m}$. diameter in the specimen, as has been shown to be essential for accurate measurement of coloured reaction products dispersed in small particles (Bitensky and others, 1973; Butcher, 1972).

It has been shown (Chayen, Bitensky, and Ubhi, 1972) that the mean activities of triplicate samples measured for lysosomal naphthylamidase activity agreed within \pm 2 per cent. Since the bound activity represents the subtraction of the free from the total activity, each value having its own standard error, the measurement of bound activity can have an error of as great as \pm 18 per cent. Thus a value of 20 per cent. bound activity may be 16.4 or 23.6 per cent.; a value of 5 per cent. bound activity may be 4 or 6 per cent.

\section{Results}

\section{Effects of glucocorticoids in vitro}

The result of maintaining non-rheumatoid synovial lining cells in vitro for up to $24 \mathrm{hrs}$ in the presence of hydrocortisone (even at $10^{-5} \mathrm{M}$ ) was that the lysosomal membranes were either unaffected or were slightly more stabilized (Table II). This effect was most clearly shown by the increased incubation time required to produce a visible acid phosphatase response. With the rheumatoid tissue, both hydrocortisone and prednisolone stabilized the lysosomes of the synovial lining cells when the concentration of these substances was $10^{-4} \mathrm{M}$; this stabilization was not observed in Specimen 1052.

\section{Effect of prednisolone in vivo}

Biopsy material (15 specimens) was examined from thirteen patients who had either been treated with non-steroidal anti-inflammatory drugs, or with prednisolone at a dosage of not more than $4 \mathrm{mg}$./day. The state of the lysosomes in the synovial lining cells was measured by determining the amount of lysosomal naphthylamidase activity which was latent, i.e. the bound activity. Thus the more stable the lysosomal membranes, the greater was the bound (latent) activity of this enzyme. It will be seen (Table III) that eleven out of the fifteen specimens had no bound activity in their synovial lining cells and that 
Table II Effect of corticosteroids on the lysosomes of human synovial lining cells in vitro

\begin{tabular}{|c|c|c|c|c|}
\hline $\begin{array}{l}\text { Specimen } \\
\text { no. }\end{array}$ & Condition & Biopsy or culture conditions & $\begin{array}{l}\text { Acid phosphatase } \\
\text { (time in min.) }\end{array}$ & $\begin{array}{l}\text { Naphthylamidase } \\
\text { (percentage bound activity) }\end{array}$ \\
\hline 1067 & Non-rheumatoid & $\begin{array}{l}\text { Biopsy } \\
\text { Normal culture } \\
\text { Normal culture }+10^{-4} \mathrm{M} \mathrm{HC}\end{array}$ & $\begin{array}{l}40 \\
40 \\
60\end{array}$ & $\begin{array}{l}35 \\
31 \\
31\end{array}$ \\
\hline 1071 & Non-rheumatoid & $\begin{array}{l}\text { Biopsy } \\
\text { Normal culture } \\
\text { Normal culture }+10^{-4} \mathrm{M} \mathrm{HC}\end{array}$ & $\begin{array}{l}20 \\
30 \\
60\end{array}$ & $\begin{array}{l}52 \cdot 3 \\
23 \cdot 7 \\
44 \cdot 5\end{array}$ \\
\hline 1116 & Non-rheumatoid & $\begin{array}{l}\text { Biopsy } \\
\text { Normal culture } \\
\text { Normal culture }+10^{-4} \mathrm{M} \text { w.s. } \mathrm{HC}\end{array}$ & $\begin{array}{l}30 \\
30 \\
30-40\end{array}$ & 二 \\
\hline 1152 & Non-rheumatoid & $\begin{array}{l}\text { Biopsy } \\
\text { Normal culture } \\
\text { Normal culture }+10^{-6} \mathrm{M} \text { w.s. HC } \\
\text { Normal culture }+10^{-5} \mathrm{M} \text { w.s. HC }\end{array}$ & $\begin{array}{l}30 \\
30 \\
30 \\
60\end{array}$ & $\bar{z}$ \\
\hline 1052 & Rheumatoid & $\begin{array}{l}\text { Biopsy } \\
\text { Culture }+10^{-4} \mathrm{M} \mathrm{HC}\end{array}$ & 二 & $\begin{array}{l}0 \\
0\end{array}$ \\
\hline 1212 & Rheumatoid & $\begin{array}{l}\text { Biopsy } \\
\text { Culture }(\mathrm{pH} 7 \cdot 4) \\
\text { Culture }+10^{-4} \mathrm{M} \text { w.s. HC }\end{array}$ & $\bar{z}$ & $\begin{array}{r}0 \\
0 \\
21\end{array}$ \\
\hline 1430 & Rheumatoid & $\begin{array}{l}\text { Culture }(\mathrm{pH} 7 \cdot 4) \\
\text { Culture }+10^{-6} \mathrm{M} \text { prednisolone } \\
\text { Culture }+10^{-5} \mathrm{M} \text { prednisolone } \\
\text { Culture }+10^{-4} \mathrm{M} \text { prednisolone }\end{array}$ & $\begin{array}{r}5 \\
5 \\
5 \\
15\end{array}$ & $\begin{array}{l}5 \\
5 \cdot 6 \\
8 \\
16\end{array}$ \\
\hline
\end{tabular}

HC $=$ hydrocortisone (alcohol soluble), w.s. HC $=$ water-soluble hydrocortisone, - not tested.

Table III Effect in vivo of prednisolone (less than $5 \mathrm{mg}$./day) or of non-steroid therapy

\begin{tabular}{lll}
\hline $\begin{array}{l}\text { Specimen } \\
\text { no. }\end{array}$ & Therapy & $\begin{array}{l}\text { Naphthylamidase } \\
\text { activity (percentage } \\
\text { bound activity) }\end{array}$ \\
\cline { 3 - 3 } 1029 & No steroid & 0 \\
1052 & No steroid & 0 \\
1057 & No steroid & 0 \\
1080 & Prednisolone $2.5 \mathrm{mg} . /$ day & 0 \\
1084 & Prednisolone $2.5 \mathrm{mg} / /$ day & 3 \\
1128 & No steroid & 0 \\
1176 & No steroid & 0 \\
1182 & No steroid & 0 \\
1211 & No steroid & 0 \\
1233 & Prednisolone $2.5 \mathrm{mg} . /$ day & 0 \\
1260 & No steroids & 0 \\
1345 & Prednisolone $4 \mathrm{mg}$./day & 6.6 \\
1429 & No steroid & 5 \\
1503 & No steroid & 4 \\
1510 & No steroid & 0 \\
\hline
\end{tabular}

only one had as much as 6.6 per cent.; this patient had been receiving the highest dose of prednisolone (4 mg./day).

Biopsy material (13 specimens) was also investigated directly from another twelve patients all of whom had been treated with at least $5 \mathrm{mg}$./day of prednisolone (Table IV). Of these thirteen specimens, five had either negligible amounts of bound activity or none. In the other eight specimens, one had 11
Table IV In vivo effect of prednisolone (at least $5 \mathrm{mg}$. (day) and ACTH

\begin{tabular}{|c|c|c|}
\hline $\begin{array}{l}\text { Specimen } \\
\text { no. }\end{array}$ & Therapy & $\begin{array}{l}\text { Naphthylamidase } \\
\text { activity (percentage } \\
\text { bound activity) }\end{array}$ \\
\hline $\begin{array}{l}1022 \\
1078 \\
1085 \\
1089 \\
1205 \\
1267 \\
1298 \\
1329 \\
1339\end{array}$ & $\begin{array}{l}\text { Prednisolone } 5 \mathrm{mg} . / \text { day } \\
\text { Prednisolone } 6 \mathrm{mg} . / \text { day } \\
\text { Prednisolone } 6 \mathrm{mg} . / \text { day } \\
\text { Prednisolone } 6 \mathrm{mg} . / \text { day } \\
\text { Prednisolone } 5 \mathrm{mg} . / \text { day } \\
\text { Prednisolone } 3 \mathrm{mg} . \text { t.d.s. } \\
\text { Prednisolone } 5 \mathrm{mg} . / \text { day } \\
\text { Prednisolone } 5 \mathrm{mg} . / \text { day } \\
\text { Acthar gel (Armour) } \\
8 \text { units daily }\end{array}$ & $\begin{array}{r}0 \\
3 \\
17 \\
19 \\
15 \\
0 \\
0 \\
11 \\
15\end{array}$ \\
\hline $\begin{array}{l}1349 \\
1373 \\
1445 \\
1462\end{array}$ & $\begin{array}{l}\text { Prednisolone } 5 \mathrm{mg} . / \text { day } \\
\text { Prednisolone } 6 \mathrm{mg} . / \mathrm{day} \\
\text { Prednisolone } 3 \mathrm{mg} \text {. bd } \\
\text { Prednisolone } 5 \mathrm{mg} . / \mathrm{day}\end{array}$ & $\begin{array}{r}18 \\
18 \\
19 \\
0\end{array}$ \\
\hline
\end{tabular}

per cent. bound activity; the others had 15 to 19 per cent. bound activity. Included in this group was one patient (Specimen no. 1339) who had received Acthar gel instead of prednisolone.

\section{Discussion}

In a previous study (Chayen and others, 1971), it was shown that the synovial lining cells from non- 
rheumatoid joints ( 9 patients) had 31 to 57 per cent. bound naphthylamidase activity; the bound activity was reduced to 28 to 40 per cent. in recently traumatized non-rheumatoid joints ( 7 patients). The biopsy results on non-rheumatoid specimens in the present study (specimens 1067 and 1071 in Table II) agree with these earlier findings. In contrast, in biopsies from patients with rheumatoid arthritis (13 patients), who had not been treated with steroids, Chayen and others (1971) found that nine had no bound naphthylamidase activity in the synovial lining cells and none had more than $5 \cdot 2$ per cent. bound activity. Very similar results have now been presented (Table III) from thirteen other rheumatoid patients who have been treated either with non-steroidal anti-inflammatory drugs, or with not more than $4 \mathrm{mg}$./day of prednisolone. Thus it seems that such treatment had no appreciable effect on the stability of the lysosomal membranes in the synovial lining cells.

In contrast, the synovial lining cells in the synovial specimens from patients treated with at least $5 \mathrm{mg}$./ day prednisolone showed more than 10 per cent. lysosomal bound activity in eight of the thirteen specimens. Thus it may be assumed that the treatment had a significant effect in these patients, although the amount of bound activity, and thus the lysosomal stability, was still far short of that found even in the recently traumatized joints in the earlier study.

The studies of Peterson and Wyngaarden (1956) indicate that steroids such as prednisolone become distributed through the extracellular body fluids. Consequently, as a rough calculation, a single dose of $5 \mathrm{mg}$. prednisolone would achieve a concentration of about $10^{-6} \mathrm{M}$ in these fluids whether they have a volume of 17 or of 11 litres. In the study in vitro (Table II) hydrocortisone and prednisolone produced appreciable stabilization of the lysosomes when present at $10^{-4} \mathrm{M}$ concentration, acting for only up to $24 \mathrm{hrs}$. Some response was found with $10^{-5} \mathrm{M}$ prednisolone; the stabilization of the lysosomal membranes (as measured by increased bound activity) appeared to be dose-dependent in that no stabilization was found with lower doses of the steroids. Thus there would seem to be a factor of at least 10 between the effects produced by these steroids in vitro and in vivo, which is not surprising in view of the relatively short exposure to them in the in vitro system.
These studies have therefore confirmed that, at a sufficient dose-level, glucocorticoids administered in vitro stabilize the lysosomes of the synovial lining cells. Of greater practical concern are the findings that they do so in most patients given at least $5 \mathrm{mg}$./day of prednisolone, but they do not stabilize in any of the patients studied who had received less than this dose. Although the latter conclusion is probably correct, these conclusions may apply only to patients with recalcitrant disease. Thus it is possible that treatment with $5 \mathrm{mg}$./day prednisolone is effective in a greater proportion of patients than is indicated by our results which necessarily are derived from those patients who, despite treatment, have come to synovectomy.

\section{Summary}

Lysosomal activity and the stability of lysosomal membranes in the synovial lining cells of human synovial tissue have been measured by quantitative cytochemistry measured specifically in the lining cells by microdensitometry. Thirteen specimens from patients treated with at least $5 \mathrm{mg}$./day of prednisolone or ACTH have been compared with fifteen specimens from patients treated with either nonsteroidal anti-inflammatory drugs alone or with $4 \mathrm{mg}$./day or less of prednisolone. It has been shown that some stabilization of these lysosomal membranes in vivo may be achieved with the higher doses of prednisolone, but that no stabilization of the lysosomal membranes of the synovial lining cells could be detected in those patients who had been treated with $4 \mathrm{mg}$./day or less of prednisolone. Although these patients form a selected population, namely of those who came to synovectomy despite treatment, two conclusions may be reached. First, that glucocorticoids administered therapeutically to patients, can stabilize lysosomal membranes of synovial lining cells; secondly that the degree of stabilization may depend on the dose administered with low doses possibly having no significant effect.

We are grateful to Mr. A. Catterall, F.R.C.S., and Mr. B. Cashman, F.R.C.S., for their interest in this work and for supplying the specimens. We are glad to acknowledge a grant towards this work from the Medical Research Council, and the support of the Arthritis and Rheumatism Council for Research.

\section{References}

Allison, A. C. (1968) 'Lysosomes' in 'The Biological Basis of Medicine', ed. E. E. Bittar and N. Bittar, vol. 1, p. 209. Academic Press, London

Ball, J. (1968) 'Post-mortem findings and articular pathology in rheumatoid arthritis' in 'Rheumatic Diseases', ed. J. J. R. Duthie and W. R. M. Alexander, p. 123. University Press, Edinburgh

BITENSKY, L. (1963) 'The reversible activation of lysosomes in normal cells and the effects of pathological conditions' in 'Ciba Foundation Symposium on Lysosomes', ed. A. V. S. de Reuck and M. P. Cameron, p. 362. Churchill, London 
Bitensky L., Butcher, R. G., AND Chayen, J. (1973) 'Quantitative cytochemistry in the study of lysosomal function' in 'Lysosomes in Biology and Pathology', ed. J. T. Dingle, vol. 3, p. 465. North Holland, Amsterdam

Butcher, R. G. (1972) Histochemie, 32, 171 (Precise cytochemical measurement of neotetrazolium formazan by scanning and integrating microdensitometry)

ChAyen, J., AND Bitensky, L. (1971) Ann. rheum. Dis., 30, 522 (Lysosomal enzymes and inflammation)

,-- , AND BUTCHER, R. G. (1973) 'Practical Histochemistry'. Wiley, London

-,$\frac{1}{-}$, AND CaShman, B. (1971) Beitr. Path., 142, 137 (Evidence for altered lysosomal membranes in synovial lining cells from human rheumatoid joints)

$-, \ldots, \ldots, \ldots$ (1973) Ibid., 149 (in press) (The effect of experimentally induced redox changes on human rheumatoid and non-rheumatoid synovial tissue in vitro)

,,,--- aND Poulter, L. W. (1969) ‘A Guide to Practical Histochemistry’. Oliver and Boyd, Edinburgh

, _ - AND UBHI, G. S. (1972) Beitr. Path., 149, 6 (The experimental modification of lysosomal dysfunction by anti-inflammatory drugs acting in vitro)

Hollander, J. L., McCarty, D. J., Astorga, G., and Castro-Murillo, E. (1965) Ann. intern. Med., 62, 271 (Studies on the pathogenesis of rheumatoid joint inflammation. I. The R.A. cell and a working hypothesis)

Lewis, D. A., AND DAY, E. H. (1972) Ann. rheum. Dis., 31, 374 (Biochemical factors in the action of steroids on diseased joints in rheumatoid arthritis)

MuIRDEN, K. D. (1972) Ibid., 31, 265 (Lysosomal enzymes in synovial membrane in rheumatoid arthritis. Relationship to joint damage)

—, AND Mills, K. W. (1971) Brit. med. J., 4, 219 (Do lymphocytes protect the rheumatoid joint?)

PAGE Thomas, D. P. (1967) 'The role of lysosomes in rheumatoid disease' in 'Rheumatology', ed. J. Rotstein, vol. 1, p. 29. Karger, Basel

- (1969) 'Lysosomal enzymes in experimental and rheumatoid arthritis' in 'Lysosomes in Biology and Pathology', ed. J. T. Dingle and H. B. Fell, vol. 2, p. 87. North Holland, Amsterdam

Peterson, R. E., AND WyngaARden, J. B. (1956) J. clin. Invest., 35, 552 (The miscible pool and turnover rate of hydrocortisone in man)

Poulter, L. W., Bitensky, L., Cashman, B., And Chayen, J. (1970) Virchows Arch. B., 4, 303 (The maintenance of human synovial tissue in vitro)

Ropes, M. W., Bennett, G. A., Cobb, S., Jacox, R., AND Jessar, R. A. (1959) Ann. rheum. Dis., 18, 49 (Diagnostic criteria for rheumatoid arthritis)

Trowell, O. A. (1959) Exp. Cell Res., 16, 118. (The culture of mature organs in a synthetic medium)

Weissmann, G. (1966) Arthr. and Rheum., 9, 834 (Lysosomes and joint disease)

- (1967) 'Structure and function of lysosomes' in 'Rheumatology', ed. J. Rotstein, vol. 1, p. 1. Karger, Basel

- (1968) 'Effect on lysosomes of drugs useful in connective tissue disease' in 'A Symposium on the Interaction of Drugs and Subcellular Components in Animal Cells', ed. P. N. Campbell, p. 203. Churchill, London

- (1969) 'Effects of steroids and drugs on lysosomes' in 'Lysosomes in Biology and Pathology', ed. J. T. Dingle and H. B. Fell, vol. 1, p. 276. North Holland, Amsterdam 